\title{
SOCIAL MEDIA AND TOURISM. \\ THE ANALYSIS OF SELECTED CURRENT \\ AND FUTURE RESEARCH TRENDS
}

\section{KRZYSZTOF STEPANIUK}

\begin{tabular}{l|l} 
& $\begin{array}{l}\text { Białystok University of Technology } \\
\text { e-mail: k.stepaniuk@pb.edu.pl }\end{array}$ \\
$\begin{array}{l}\text { RECEIVED } \\
\text { ACCEPTED }\end{array}$ & $\begin{array}{l}25 \text { March } 2015 \\
6 \text { July } 2015\end{array}$ \\
CLASSIFICATION & $\begin{array}{l}\text { O35, Z19 } \\
\text { KEYWORDS }\end{array}$ \\
ABSTRACT & $\begin{array}{l}\text { The issue of the article concerns the analysis of current research trends related to tourism and social media. } \\
\text { Based on the results of a critical analysis of the literature, an outline of the directions of future scientific research } \\
\text { in this area was also shown. These studies of interdisciplinary nature would include the issues from the field of } \\
\text { social and economic sciences with particular emphasis on crowdsourcing and the possibilities of its implemen- } \\
\text { tation in the social media for the development of tourism in the region. }\end{array}$
\end{tabular}

\section{Introduction}

The paper presents a review of the current scientific literature relating to the topic of social media applications in tourism. Major research trends were identified and the forecasts for future directions of scientific research in this area were examined. The comparative analysis of scientific literature was used as the main research method. 
The heuristic method was used to develop causal relationships and structures associated with the future research trends focused on the issues of social media and tourist relationships.

\section{Tourism and social media - multithreading nature of scientific research}

Scientific research in tourism has a multidisciplinary character (Liburd, 2012). The phenomenon of multidisciplinarity is widely shown in the topics of scientific papers focused on economic, environmental, sociological, psychological aspects of social media used in tourism.

The social media are defined as "a group of Internet-based applications that build on the ideological and technological foundations of Web 2.0, and that allow the creation and exchange of user-generated content" (Kaplan, Haenlein, 2010).

The latest papers (2012-2015) show the possible directions of future studies related to the topic of the social media. It seems that the basis for considering the implementation of the existing scientific theories for the analyses related to the social media in tourism is the work of Ngai, Tao and Moon (2015). The authors analysed the scientific works from the years 2002-2011, which focused on the issues related to the use of scientific theories, the formation of research constructs in scientific research involving tourism and SM. The theoretical base for the considerations of the cited work are three main groups of scientific theories in social sciences. These include: Personal Behaviour Theories (e.g. Technology Acceptance Model (Davis, 1989); Theory of Planned Behavior (Ajzen, 1985)), Social Behaviour Theories (e.g. Involvement Theory (Huang, 2010); Social Interaction Theory (Fischer, Reuber, 2011)), and Mass Communication Theories (e.g. Uses and Gratifications Theory (Chen, 2010)).

A part of the published research activities relates to the issue of the involvement of users. According to Hollebeek (2010), engagement, in strictly tourist matters, can be viewed from the perspective of mutual interaction taking place between tourists and other objects, such as tourist attractions, reception areas, brand names, trademarks, etc. In the case of social media, engagement can be defined as all the activities of users in relation to the activities carried out through these media and concerning a certain object, place, product or service. This phenomenon can be analysed in relation to individual persons or groups (communities).

From the perspective of managing the involvement of tourist community members and other users of the social media, the theme of the research activities belongs to several key areas. First of all the impact of SM activities on the level of the involvement of the users was analysed. Dijkmans, Kerkhof and Beukeboom (2015) studied the impact of the activities in the social media of a company in the aviation industry on the level of corporate reputation, and the involvement of users in the company's initiatives in the SM. The impact of the social media on the market position of tourism companies, on the example of the TripAdvisor website, was analysed by Scott and Orlikowski (2012).

Secondly, the issue of managing the involvement of users is considered. Cabiddu, Carlo and Piccoli (2014) described this phenomenon in the context of persistent, customized, and triggered engagement. Building user involvement was conditioned by the way of presenting content concerning the entity. This concerned the so called form of exteroception, i.e. the presentation of the properties of the social media, proprioperception associated with the accentuation of the intrinsic characteristics of the entity and coperception - the method of presenting content connecting the two previous modes.

Thirdly, the issues concerning the operation of the virtual groups and communities is examined. The dynamics of the development of online communities was described by Fortunati, Taipale and Luca (2013). At the same time 
(Kavoura, Stavrianea, 2014) consider the issues concerning the advisability of building virtual communities, centred on a tourist destination. Kang, Tang and Fiore (2014) analyse the affiliation to groups created around catering facilities from the perspective of psychological, social and economic profits. A very interesting, although not reflected in the tourism sector, approach to building user engagement through cocreating products and services is presented by Lorenzo-Romero, Constantinides and Brünink (2014). Hedonic benefits, personal integrated benefits, social benefits and integrated learning benefits were identified as the main building blocks of sustainable involvement of users in the activity of companies in social media.

In turn, slightly other determinants inducing aggregation were demonstrated for virtual groups centred on the theme of sports. Stavros et al. (2014), based on the analysis of the content of comments among the NBA basketball league fan community, showed that the main motives driving the users to join the virtual group are: passion expressed in a strong bond with the team, hope - externalized by the expression of the expectations concerning the rise of the significance and the achievements of the team, esteem - related to the need for recognition among the people commenting on the achievements of the team, and camaraderie - allowing for joint interaction, aimed at solving the problems of the group, acquiring new knowledge and skills, etc.

Floreddu, Cabiddu and Evaristo (2014) analyse and prioritize interactions with the users of social media. The hierarchy of ways to communicate with the use of the SM and including the criteria proposed by Balmer and Gray (1999) is used as the basis., i.e.: primary communication (the various communication effects of product and service performance, firm policies, and employee behaviour); secondary (formal communications of the organization, making use of traditional communication channels including advertising, public relations, and sponsorship); and tertiary (word of mouth, media interpretation, and competitor communication). In addition, a further two forms of interaction have been applied, including reservations and customer engagement

The study concerning the applications of the social media, also apply to the issue of marketing. Constantinides (2014) proposes two alternative strategies for the marketing use of SM, i.e. a passive strategy, associated with the use of SM as a source of information about the consumer needs, and an active strategy, focused on the use of SM as the main channel of information about the offered products and services. Not without significance is also the use of SM as a medium for the construction of a platform for cooperation with the users. Supporting brand loyalty through the use of social media was analysed by Laroche, Habibi and Richard (2013). The problem of using social media in communication and branding was also analysed by Jaska and Werenowska (2014). Liu et al. (2016) describe five tourist brand personality factors (humanity, excitement, status enhancement, professionalism and wellness), which potentially helps consumers to develop a favourable image of the company. Such an approach can be taken into account towards social media. In turn, Muntinga, Moorman and Smit (2011) present the typology of the activity of SNS users based on the level of consumption of the shared pieces of content without distinction of the affective stage, indicating: the lowest level of content consumption (e.g. viewing pictures and reading product/service descriptions, reviews); a moderate level of contributions to page content (e.g. rating products/services/companies, commenting on posted pictures or photos); the highest level of contribution, which refers to creating and sharing user-generated content.

Similarly, Gal-Tzur, Grant-Muller and Minkov (2014) describe the typology of information related to the functions of SM, which are mostly used by operators in the transport industry to communicate with users. These are: informational function, referring to informing the users about the changes introduced on the website of the entity, about the undertaken initiatives, organized events, etc.; advisory function, relating to showing users the possible 
ways to solve the problems associated with the activity undertaken, but not being the result of user questions, for example we recommend specific equipment, in the case of the desire to slenderize the figure we recommend a specific set of exercises, etc.; educational function (administrator acts as a mentor, an expert), the activity of the administrator associated with the possibility to answer the questions asked by the users; communicative function, encompassing mainly the conversations with the users that involve technical issues related to the operation of the profile, function associated with sending occasional wishes (e.g. associated with the celebration of Christmas, Easter, etc.). UGC methodology analysis concept in the context of building a competitive advantage of economic operators described by He, Zha and Li (2013). The UGC methodology analysis focused on food quality was described by Tiago, Amaral and Tiago (2014).

The problem of knowledge sharing in social media in tourism sector was analysed by Nezakati et al. (2015).

Part of the studies include, inter alia creating the interest of social media users. Regarding the problems of mass events, Hudson et al. (2015) studied the impact of these media on the level of the interest in music festivals. The authors demonstrated the important role of SM in creating a positive image of an event, through inter alia, word of mouth. Similarly the use of the social media in the creation of promotional activities of museums was described by Padilla-Meléndez and del Águila-Obra (2013). At the same time, the approach related to supporting the development of individual competencies of users is also important. Sigala and Chalkiti (2015) analysed the impact of the social media on the level of creativity of Greek workers of tourist companies, with particular emphasis on the issue of knowledge management (knowledge management approach). The impact of the social media on building personal brands was described by Karaduman (2013). A slightly different approach to this issue is adopted by Zolkepli and Kamarulzaman (2015), who, taking into account the attributes of innovation by Rogers (1995), evaluated the impact of innovation on the level of acceptance and adaptation of the social media by the users. Personal needs (mainly related to entertainment), social needs (associated with the need to maintain interactions with other users) and the need of belonging to a group, which in turn are motivated by the innovative attributes of SM were indicated as the main factors stimulating the users to be active in social media.

From another perspective, SM are examined by Olsen and Christensen (2015), who describe the possibility of the use of SM in the context of crowdsourcing i.e. the phenomenon of solving complex problems based on user experience, and not on the specialists employed for this purpose. The educational value of the content presented in the SM was also emphasized by (Bandias, Gilding, 2012).

The role of the social media in shaping the behaviours related to trip planning is a very common topic of research papers. Xiang, Magnini and Fesenmaier (2015) analyse the impact of the development of the Internet and the social media on the behaviours associated with trip planning by the representatives of the $Y$ generation, i.e. people born at the turn of the XX and XXI century. The usage of the social media in the planning of the tourist activity of the users was analysed by Jacobsen and Munar (2012). Similar issues, in relation to the consumer behaviour of the customers of hotels, were presented by Biełuszko (2014).

\section{Future research directions}

Future research related to the use of the social media in tourism will have a decidedly multi-threaded nature, requiring a multidisciplinary approach grounded in scientific theories from many disciplines, including economic sciences - more precisely management sciences and the social sciences (mostly legal sciences). 
Ngai, Tao and Moon (2015) indicate the potential directions for future research concerning tourism and the social media. They mainly include the possibility of the practical use and analysis of the data obtained through the $\mathrm{SM}$, ways to interact with the users, especially in the context of the use of their knowledge and skills to effectively create and develop business.

In turn, Zeng and Gerritsen (2014) present a somewhat broader approach to the future of research in the use of SM in tourism. As the main topics for future research activities the authors distinguish community engagement, comprehensive marketing strategies, differentiated destination management, and the legal and ethical issues.

The social media and the content made available through their use are primarily an unlimited source of information about the users. This data constitutes the basis for conclusions about the real impact of SM on motivation, behaviour (including consumer behaviour), decisions, lifestyle and preferences of users. The issues stimulating, creating and directing users to the specific activities in the area of tourism could play an important role in future research. This data can be analysed across different disciplines.

The phenomenon of crowdsourcing - i.e. the search for solutions to problems using the knowledge and experience of the users of SM appears to be interesting in the discipline of management sciences, from the perspective of building effective destination management models, or creating strategies to develop new products and services. Linking it to the activities towards building numerous and active communities, clustered around a certain tourist theme could be an interesting area of research focused on the emergence of unconventional solutions in the field of tourism in the region. Such solutions could include, for example: creating innovative solutions in the field of tourist products and services, plotting their respective marketing strategies, market positioning strategy, etc. The possibilities of the social media in this regard could be used to strengthen the studies with the use of foresight tools - this type of work was implemented, among others, by Szpilko (2014). The issues of effective communication with the users of the social media (relationship management), the exchange of experiences and analysis of their

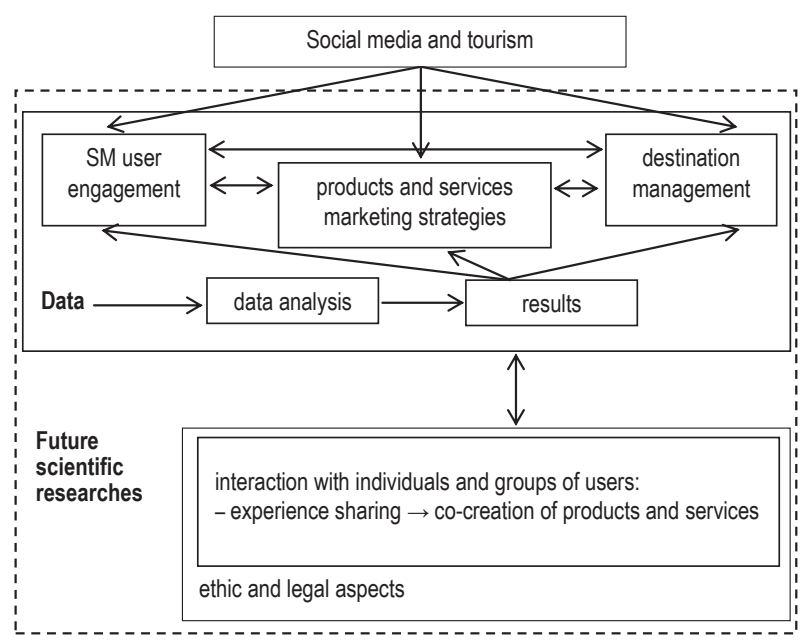

Figure 1. Graphical layout of the relationship between the different areas of research in terms of the feasibility of research related to tourism and Social Media

Source: own study. 
activity in relation to the actions taken by entities active in the social media and related to a specific tourism region are relevant in this case. Research on the semantic and epistemological aspects of user activity in this case would be of subsidiary nature.

Another area of future research concerning the use of the social media in tourism could be building the support for innovative and sustainable management of the development of the reception area, with particular emphasis on identifying new directions of the development of destinations in today's competitive tourist market, etc.

In both of the above-mentioned cases, primarily modelling of the management of the involvement of users both on an individual basis, as well as based on various communities formalized around a certain theme could be crucial for this type of discussion. This would primarily concern the methodology of building and maintaining lasting relationships with regard to stimulating the members of the community to undertake activities of a creative nature.

In terms of legal sciences, future research could focus on the issue of the relationship with the users in terms of their contribution to the copyright, potential patents, protection of data relating to privacy, etc.

Graphic image, relating to the above considerations is presented in Figure 1.

\section{Conclusions}

The use of the social media in tourism is undoubtedly a very broad topic, forcing a multidisciplinary approach in the scientific research. Hence, there is a need to locate this subject within the area of scientific theories relating to both the social and economic sciences. Future research in the field of tourism and the social media primarily involves modelling the interaction with users through the phenomenon of crowdsourcing. These issues should primarily concern the involvement and use of their powers in order to implement efficient and innovative tourist products and services as well as the issues related to the management of tourist destinations. Ethical and legal issues concerning future research also remain not without significance.

\section{References}

Ajzen, I. (1985). From intentions to actions: A theory of planned behavior. In: J. Kuhl \& J. Beckman. Action-control: From cognition to behawior. Heidelberg: Springer, Ch.2.

Balmer, J.M.T. \& Gray, E.R. (1999). Corporate identity and corporate communications: Creating a competitive advantage. Corporate Communications: An International Journal, 4 (4): 171-177.

Bandias, S. \& Gilding, A. (2012). Social media: the new tool in business education. In: Public Interest and Private Rights in Social Media. Chandos Publishing, Ch.7.

Biełuszko, K. (2014). Opiniotwórcza rola mediów społecznościowych w kształtowaniu zachowań nabywczych klientów hoteli. Dynamika Przemian Rynku Turystycznego, 1: 213-229.

Cabiddu, F., Carlo, M.D. \& Piccoli, G. (2014). Social media affordances: Enabling customer engagement. Annals of Tourism Research, 48: 175-192.

Chen, G.M. (2010). Tweet this: A uses and gratifications perspective on how active Twitter use gratifies a need to connect with others. Computers in Human Behavior, 27 (2): 755-762.

Constantinides, E. (2014). Foundations of Social Media Marketing. Procedia - Social and Behavioral Sciences, 148: 40-57.

Davis, F.D. (1989). Perceived usefulness, perceived ease of use, and user acceptance of information technology. MIS Quarterly, 13 (3): 319-340.

Dijkmans, C., Kerkhof, P. \& Beukeboom, C.J. (2015). A stage to engage: Social media use and corporate reputation. Tourism Management, 47: 58-67.

Fortunati, L., Taipale, S. \& de Luca, F. (2013). What happened to body-to-body sociability? Social Science Research, 42 (3): $893-905$. 
Fischer, E. \& Reuber, A.R. (2011). Social interaction via new social media: (How) can interactions on Twitter affect effectual thinking and behavior. Journal of Business Venture, 26: 1-18.

Floreddu., P.B., Cabiddu, F. \& Evaristo, R. (2014). Inside your social media ring: How to optimize online corporate reputation. Business Horizons, 57 (6): 737-745.

Gal-Tzur, A., Grant-Muller, S.M. \& Minkov, E. (2014). The Impact of Social Media Usage on Transport Policy: Issues, Challenges and Recommendations. Procedia - Social and Behavioral Sciences, 111: 937-946.

He, W., Zha, S. \& Li, L. (2013). Social media competitive analysis and text mining: A case study in the pizza industry. International Journal of Information Management, 33 (3): 464-472.

Huang, C.Y., Chou, C.J. \& Lin, P.C. (2010). Involvement theory in constructing bloggers' intention to purchase travel products. Tourism Management, 31 (4): 513-526.

Hollebeek, L.D. (2010). Demystifying customer brand engagement: exploring the loyalty nexus, Journal of Marketing Management, 27 (7-8): 785-807.

Hudson, S., Roth, M.S., Madden, T.J. \& Hudson, R. (2015). The effects of social media on emotions, brand relationship quality, and word of mouth: An empirical study of music festival attendees. Tourism Management, 47: 68-76.

Jacobsen, J.K.S. \& Munar, A.M. (2012). Tourist information search and destination choice in a digital age. Tourism Management Perspectives, 1: 39-47.

Jaska, E. \& Werenowska, A. (2014). The use of social media in communication and branding, Economics and Law, 13 (1): 47-58.

Kang, J., Tang, L. \& Fiore, A.M. (2014). Enhancing consumer-brand relationships on restaurant Facebook fan pages: Maximizing consumer benefits and increasing active participation. International Journal of Hospitality Management, 36: 145-155

Kaplan, A.M. \& Haenlein, M. (2010). Users of the world, unite! The challenges and opportunities of Social Media. Business Horizons, 53: $59-68$.

Karaduman, I. (2013). The Effect of Social Media on Personal Branding Efforts of Top Level Executives. Procedia - Social and Behavioral Sciences, 99: 465-473.

Kavoura, A. \& Stavrianea, A. (2014). Economic and Social Aspects from Social Media's Implementation as a Strategic Innovative Marketing Tool in the Tourism Industry. Procedia Economics and Finance, 14: 303-312.

Laroche, M., Habibi, M.R. \& Richard, M. (2013). To be or not to be in social media: How brand loyalty is affected by social media? International Journal of Information Management, 33 (1): 76-82.

Liburd, J.J. (2012). Tourism research 2.0. Annals of Tourism Research, 39 (2): 883-907.

Liu, Z., Huang, S., Hallak, R. \& Liang, M. (2016). Chinese consumers' brand personality perceptions of tourism real estate firms. Tourism Management, 52: 310-326.

Lorenzo-Romero, C., Constantinides, E. \& Brünink, L.A. (2014). Co-creation: Customer Integration in Social Media Based Product and Service Development. Procedia - Social and Behavioral Sciences, 148: 383-396.

Muntinga, D.G., Moorman. M., \& Smit, E.G. (2011). Introducing COBRA's: exploring motivations for brand-related social media use. International Journal of Advertising, 30 (1): 13-46.

Nezakati, H., Amidi, A., Jusoh., Y.Y, Moghadas, S., Yuhanis, A.A. \& Sohrabinezhadtalemi, R. (2015). Review of Social Media Potential on Knowledge Sharing and Collaboration in Tourism Industry. Procedia - Social and Behavioral Sciences, 172 (27): $120-125$.

Ngai, E.W.T., Tao, S.S.C. \& Moon, K.K.L. (2015). Social media research: Theories, constructs, and conceptual frameworks. International Journal of Information Management, 35 (1): 33-44.

Olsen, N.V. \& Christensen, K. (2015). Social media, new digital technologies and their potential application in sensory and consumer research. Current Opinion in Food Science, 3: 23-26.

Padilla-Meléndez, A. \& del Águila-Obra, A.R. (2013). Web and social media usage by museums: Online value creation. International Journal of Information Management, 3 (5): 892-898.

Rogers, E. (1995). Diffusion of Innovations. New York: Free Press.

Scott, S.V. \& Orlikowski, W.J. (2012). Reconfiguring relations of accountability: Materialization of social media in the travel sector. Accounting, Organizations and Society, 37 (1): 26-40.

Sigala, M. \& Chalkiti, K. (2015). Knowledge management, social media and employee creativity. International Journal of Hospitality Management, 45: 44-58.

Stavros, C., Meng, M.D., Westberg, K. \& Farrelly, F. (2014). Understanding fan motivation for interacting on social media. Sport Management Review, 17 (4): 455-469. 
Szpilko, D. (2014). The Methods Used in the Construction of a Tourism Development Strategy in the Regions. A Case Study of Poland. Procedia - Social and Behavioral Sciences, 156: 157-160.

Tiago, T., Amaral, F. \& Tiago, F. (2015). The Good, the Bad and the Ugly: Food Quality in UGC. Procedia - Social and Behavioral Sciences, 175: 162-169.

Xiang, Z., Magnini, V.P. \& Fesenmaier, D.R. (2015). Information technology and consumer behavior in travel and tourism: Insights from travel planning using the internet. Journal of Retailing and Consumer Services, 22: 244-249.

Zeng, B. \& Gerritsen, R. (2014). What do we know about social media in tourism? A review. Tourism Management Perspectives, 10: 27-36.

Zolkepli, I.A. \& Kamarulzaman, Y. (2015). Social media adoption: The role of media needs and innovation characteristics. Computers in Human Behavior, 43: 189-209.

Cite this article aS: Stepaniuk, K. (2015). Social media and tourism. The analysis of selected current and future research trends. Szczecin University Scientific Journal, No. 883. Service Management, 16 (2): 153-160. 